\title{
DINAMIKA KONFLIK TOKOH DALAM NOVEL KIDUNG RINDU DI TAPAL BATASKARYA AGUK IRAWAN MNKAJIAN PSIKOLOGI SASTRA
}

\author{
Sumadi \\ SDN Banjarmadu Kec. Karanggeneng Kab. Lamongan \\ HP081615335789 ; pos-el sumadi2016@yahoo.com
}

\begin{abstract}
Abstrak: Penelitian ini bertujuan untuk mendeskripsikan (1) wujud dinamika konflik yang dialami para tokoh dan (2) faktor-faktor penyebab terjadinya konflik.dalam novel Kidung Rindu di Tapal Batas karyaAguk Irawan MN. Penelitian ini merupakan penelitian deskriptif kualitatif dengan menggunakan pendekatan Psikologi Sastra.Data diperoleh dengan teknik baca dan catat dan dianalisis dengan teknik analisis deskriptif kualitatif. Hasil penelitian ini menunjukkan: (1) ada dua wujud dinamika konflik yaitu konflik internal dan eksternal, lima konflik yang dominan meliputi, kegelisahan terhadap apa yang sudah terjadi, perbedaan pendapat, ketakutan terhadap ancanman keamanan, perasaan yang terlukai, kekecewaan akibat kurang diperhatikan, (2) faktorfaktor penyebab konflik yang terdiri dari: terjebak dalam situasi rumit,ketidaknyamanan dengan kondisi yang ada, perbedaan prinsip dan pola pikir, kenyataantidak sesuai dengan harapan, dan hadirnya pandangan baru.
\end{abstract}

Kata kunci: dinamika konflik, konflik internal, eksternal, psikologis sastra, novel

\begin{abstract}
This study aims to describe (1) the form of conflict dynamics experienced by the figures and (2) the factors causing the conflict in Kidung Rindu novel in Tapal Batas Aguk Irawan MN work. This research is a qualitative descriptive research using approach of Psychology Sastra.Data obtained by reading and record technique and analyzed by qualitative descriptive analysis technique.The results of this study show: (1) There are two forms of conflict dynamics: internal and external conflicts, the five dominant ones include, anxiety over what has already happened, disagreements, fear of security threats, feelings of hurt, disappointment due to lack of attention, (2) Conflicting factors consisting of: trapped in complicated situations, discomfort with existing conditions, Differences in principles and mindset, reality is not in line with expectations, and the presence of new views. (3) The way to solve conflicts of characters includes, giving understanding, self-control, resignation to the circumstances, the search for truth, self-awareness, determination to makechanges, submitting to God.
\end{abstract}

Keywords:dynamics of conflict, internal conflict, external conflict, psychological literature, novel

\section{PENDAHULUAN}

Karya sastra merupakan suatu karya yang artistik, karena karya sastra terbentuk dari proses imajinatif dan proses realitas objektif. Karakteristik karya sastra akan menimbulkan berbagai macam pemikiran dan kesimpulan dari pembaca atau penikmat terhadap sebuah karya sastra.

Karya sastra tidak akan terlepas dari pengarangnya. Melalui karya sastranya, pegarang ingin berpesan 
kepada orang lain mengenai seluk beluk permasalahan yang terjadi dalam kehidupan.

Kejadian atau peristiwa yang terdapat dalam karya sastra dihidupkan oleh tokoh-tokoh.Melalui perilaku tokoh yang ditampilkan menggambarkan kehidupan manusia dengan berbagai masalah dan konflik yang dihadapi, baik konflik dengan orang lain, konflik dengan lingkungan, maupun konflik dengan diri sendiri.

Melalui kehadiran karya sastra pembaca dapat memahami konflik atau kejadian yang ada dalam kehidupan sosial, budaya, dan politik saat karya sastra itu dihasilkan. Dari karya sastra, pembaca juga dapat membaca maksud atau tujuan pengarang dalam membuat karya sastra tersebut.

Seorang pembaca karya sastra akan lebih mengenal dengan jelas maksud cerita, apabila mereka memahami karakter tokoh-tokoh dalam cerita. Menurut Abrams (dalam Nurgiyantoro, 2009 : 165), tokoh cerita (character) adalah orang yang ditampilkan dalam suatu karya naratif atau drama yang oleh pembaca ditafsirkan memiliki kualitas moral dan kecenderungan tertentu seperti yang diekspresikan dalam ucapan dan apa yang dilakukan dalam tindakan.

Novel merupakan sebuah totalitas suatu keseluruhan yang bersifat artistik. Sebagai sebuah totalitas, novel mempunyai bagian-bagian, unsur- unsur yang saling berkaitan satu dengan yang lain secara erat. Unsur-unsur pembangun sebuah novel yang bersama membentuk sebuah totalitas itu, disebut unsur intrinsik dan ekstrinsik. Menurut Nurgiyantoro (2009:23) unsur-unsur intrinsik adalah unsur yang membangun sebuah karya sastra dari dalam. Unsurunsur tersebut antara lain tema, plot, cerita, pernokohan, latar, dan sudut pandang. Unsur ekstrinsik adalah unsur yang berada di luar karya sastra itu, tetapi secara tidak langsung mempengaruhi bangunan atau sistem organisme karya sastra. Unsur-unsur ekstrinsik tersebut antaralain psikologi, sosial, ekonomi, politik, dan biografi pengarang.

Penelitian ini akan menganalisis salah satu ragam sastra yaitu novel yang berjudul Kidung Rindu di Tapal Batas karya Aguk Irawan MN. Novel ini adalah salah satu karya Aguk Irawan MN,

Pembahasan tentang unsur konflik tokoh dalam novel menjadi sangat menarik dan perlu dikaji karena sebuah novel akan menjadi semakin diminati oleh pembaca ketika dalam novel tersebut terdapat konflik-konflik yang menarik, sensasional, menyentuh, dan menegangkan. Menurut Wellek \&Warren (dalam Nurgiyantoro, 2009: 122), konflik adalah sesuatu yang dramatik, mengacu pada pertarungan antara dua kekuatan yang seimbang dan menyiratkan adanya aksi dan aksi balasan.

Pemahaman terhadap konflik yang terjadi pada tokoh-tokoh dalam novel ini akansemakin jelas apabila diungkap dengan menggunakan berbagai pendekatan. Satu diantara pendekatan yang ada dan cocok untuk digunakan adalah pendekatan psikologi.

Menurut Endraswara (2008:97) psikologi sastra sebagai kajian sastra yang memandang karya sebagai aktivitas kejiwaan, yaitu jiwa manusia yang terpantul melalui tingkah laku aktivitasaktivitasnya sebagai manifestasi hidup psikis.

Berdasarkanpaparan di atas perlu adanya penelitian yang bertujuan untuk mendeskripsikan (1)Wujuddinamika konflik yang dialami tokoh-tokoh dalam novel Kidung Rindu di Tapal Batas karyaAguk Irawan MN. (2)Faktor-faktor penyebabkonflik (3) Penyelesaian konflik 


\section{METODE PENELITIAN}

Penelitian ini termasuk dalam penelitian deskriptif kualitatif.Menurut Moleong (dalam Arikunto, 2013:22),metode kualitatif yang bersifat deskriptif dimaksudkan adalah bahwa data yang dikumpulkan berupa katakata, gambar, dan bukan angkaangka.Pendekatan yang digunakan dalam penelitian ini adalah pendekatan psikologi sastra.Psikologi sastra adalah kajian sastra yang memandang karya sastra sebagai aktivitas kejiwaan (Endraswara, 2008: 96).

Data dalam penelitian ini berupa paparan bahasa (teks tertulis) yaitu katakata, frase, kalimat dan paragraf yang berkaitan dengan wujud dinamika konflik yang dialami para tokoh, faktorfaktor penyebab konflik yang dialami para tokoh dan penyelesaian konflik yang terjadi pada para tokoh dalam novel Kidung Rindu di Tapal Batas karya Aguk Irawan MN.Sumber data dalam penelitian adalah novel Kidung Rindu di Tapal Batas Karya Aguk Irawan MN.

Teknik pengumpulan data dalam penelitian ini dilakukan dengan teknik membaca dan mencatat. Teknik membaca berkaitan dengan membaca dan memahami teks novel sedangkan teknik mencatat digunakan untuk mencatat data atau informasi tentang wujud dinamika konflik yang dialami para tokoh, faktorfaktor penyebab konflik yang dialami para tokoh dan penyelesaian konflik yang terjadi pada para tokoh dalam novel Kidung Rindu di Tapal Batas karya Aguk Irawan MN.

Penelitian ini dianalisis dengan menggunakan tinjauan psikologi sastra. Analisis data dilakukan dengan cara mendeskripsikan wujud dinamika konflik, faktor-faktor penyebab konflik dan penyelesaian konflik yang terjadi pada para tokoh dalam novel Kidung
Rindu di Tapal Batas karya Aguk Irawan $\mathrm{MN}$.

\section{HASILPENELITIAN}

Hasil penelitian yang diperoleh berupa deskripsi mengenai wujud dinamika konflik yang dialami para tokoh, faktor penyebab konflik, dan cara penyelesaiannya. Hasil penelitian ini, dibahas dalam tiga bagian sesuai dengan deskripsi tujuan penelitian. Berikut ini uraian ketiga pokok permasalahan tersebut.

\section{Wujud Dinamika Konflik Tokoh}

Ada dua wujud dinamika konflik yang dialami oleh para tokoh.Pertama,wujud dinamika konflik internalyang meliputi; kegelisahan terhadap apa yang sudah terjadi, ketakutan ditinggal warganya,kebingungan menghadapi dilema kehidupan, keinginan penghidupan yang lebih baik, ketakutan terhadap kematian, takut melukai perasaan orang lain, kekhawatiran yang beralasan, kekecewaan terhadap pengabdian yang kurang dihargai, perasaan bersalah atas perbuatannya, ketakutan terhadap perilaku yang diperbuat. Kedua,wujud dinamika konflik eksternalyang meliputi; perbedaan pendapat, ketakutan terhadap ancaman keamanan, perasaan yang dilukai, kekecewaan akibat kurang diperhatikan, pertentangan antara harapan dan kenyataan, bayangan kesulitan yang akan terjadi, pilihan yang sulit, ketidakpercayaan pada pemerintah, anggapan yang salah. Menurut Sigmund Freud sumber dari konflik terdapat dalam beberapa teori kepribadian yaitu adanya pertetangan antara sistem id, ego, dan super ego. Di bawah ini akan diuraikan lima wujud dinamika konflik yang dominan yaitu: 


\section{Kegelisahan Terhadap Apa yang Sudah Terjadi}

Konflik internal ini dialami beberapa tokoh diantaranya; Nanjan, Carnelius, Iskandar, Siti, Hasyim, Felix, Hamdan, Pang Ukir, dan Nei, yang berwujud kegelisahan terhadap apa yang sudah terjadi. Nanjan dan orang-orang yang tinggal disana mengganggap tinggaldi daerah perbatasan sangat menguji kesabarannya diri mereka.

"Tunggu sebentar, lihatlah!" Nanjan menunjuknunjuk dua anjing dan tiga askar Diraja Malaysia yang bergerak belasan meter di belakang lelaki malang itu. "( Irawan,2015:31)

Kutipan di atas, merupakan teriakan dan sekaligus ajakan Nanjan untuk menahan diri bersama teman lainnya. Naluri kuatnya untuk segera menolong pada orang yang sangat membutuhkan pertolongan itu adalah dorongan $i d$, Sementara kalau nekat menolongnya bisa jadi dia sendiri yang kena sasaran. Super ego yang mendorong Nanjan untuk menahan niat kuatnya untuk menolong orang tersebut.

"Bang Hasyim jangan kau anggap sikapku selama ini buruk karena aku benci kau.Tidak. Aku tan benci kau. Nasipmu buruk dan tak pantas untuk dibenci.Aku rela menukar nyawaku dengan nyawamu di tanga askar Diraja Malaysia.Jika aku kau anggap buruk, itu karena nasip kami tak kalah buruknya dengan nasipmu.Bedanya kau orang sipil, dan kebetulan TKI illegal.Aku prajurit, kewajibanku bela Negara, hingga lupa membela nasipnya sendiri." (Irawan,2015:120)

Kutipan di atas, merupakan kegelisaan Cornelius terhadap apa yang sudah terjadi selama ini, karena selama Hasyim numpang di barak tentara, Cornelius sering berkata kasar pada Hasyim. Cornelius tahu hal ini sering dilakukannnya terhadap diri Hasyim lepas dari kontrolnya ini adalah dorongan dari id tetapi kemudian dorongan id itu tertahan dengan dorongan egonya sehingga ia menyadari hal itu tidak baik. Hal demikian merupakan dasar terjadinya konflik internal yang dialami Cornelius.

\section{PerbedaanPendapat}

Konflikini banyak dialami oleh tokoh, misalnya kutipan ini:

"Lebih baik Anda biarkan orang itu, agar kami bisa menangkapnya!" seruh salah satu askar yang tampaknya adalah pimpinan dari ketiganya.Iaberseruh dari balik pohon kepada Iskandar dan Cornelius. Iskandar pun menjawab," lebih baik Anda biarkan dia, sebab dia sudah masuk ke wilayah kami!". (Irawan, 2015: 32)

Kemarahan Iskandar ini merupakan dorongan id.Dan kemarahannya ini dikarenakan adanya perbedaan pendapat.

\section{Ketakutan Terhadap Ancaman Keamanan}

Ketakutan terhadap ancaman keamananmerupakanwujudkonflik eksternalyang dialami beberapa tokoh; Iskandar, Hasyim, Mamut, dan Apong,mereka merasa ketakutan jika keamanan yang ada pada diri terganggu.

"Telingan Hasyim mendengar suara anjing menyalak di kejauhan. Ini adalah malam pertama setelah berbulan-bulan berada di sini di mana ia mendengar suara anjing yang menyalak-nyalak. Hasyim curiga. Dadanya berdebar-debar. Bayangan yang amat buruk segera melintas di benaknya." (Irawan,2015:54)

Kutipan di atas, menunjukkan rasa ketakutannya Hasyimterhadap ancaman keamanan pada dirinya. Karena dia adalah TKI illegal. Ketakutan yang dialami Hasyim ini dorongan dari sistem $i d$ nya.

\section{Perasaan yang Dilukai}

Konflik ini terjadi ketika tokoh Nei mendapatkan perasaan yang dilukai atau perasaan yang disakiti.

"Tega sekali Ibu berkata begitu-di saat hatiku masih sedih karena kehilangan suamiku?"(Irawan, 2015:75)

Kutipan di atas, merupakan kejadian yang tidak menyenangkan dan menyakitkan yang dialami Nei. Kemarahan yang dia ungkapkan itu merupakan dorongan idnya. Peristiwa 
yang ia alami ini sungguh melukai hatinya.

\section{Kekecewaan Akibat Kurang Perhatian}

Kekecewaan terjadi akibat antara kenyataan dan harapan bertolak belakang, sehingga menimbulkan rasa kekecewaan.

"Garuda ini kalian tahu selalu ada di dada ini. Warna merah putih itu, menjadi warna darahku.Dapatkan kalian melihat betapa air mataku berdarah-darah, menyaksikan merah putih yang semakin kusam berkibar-kibar? Lihatlah bendera Malaysia sana: Ia berkibar cemerlang di puncak-puncak galah yang tinggi, di atas tanah yang makmur di atas atap-atap rumah penduduk yang bahagia. Setiap kali memandang merah putih, aku merasa sedih dan sengsarah atas nasip kita yang tak pernah diperhatikan. (Irawan,2015:104)

Kutipan di atas, menggambarkan perasaan kecewa Nanjan terhadap pemerintah yang mengabaikan nasibnya. Rasa kesal dan kecewa itu bersumber dari dorongan sistem id. Pemicu dorongan ini karena ia merasa kurang ada perhatian dari pemerintah pusat dan bahkan cenderung diabaikan.

\section{Faktor Penyebab Konflik Tokoh}

Para tokoh dalam novel Kidung Rindu di Tapal Batas banyak mengalami konflik, baik konflik internal maupun konflik eksternal.Terjadinya konflik tersebut disebabkan oleh beberapa faktor diantaranya adalah terjebak dalam situasi rumit, ketidaknyamanan dengan kondisi yang ada, perbedaan prinsip dan pola pikir, kenyataan tidak sesuai dengan harapan, dan hadirnya pandangan baru. Berikut ini deskripsi faktor penyebab terjadinya konflik para tokoh dalam novel Kidung Rindu di Tapal Batas karya Aguk Irawan $\mathrm{MN}$.

\section{Terjebak Situasi Rumit}

Faktor eksternal penyebab konflik berupa terjebak situasi rumit ini banyak dialami oleh para tokoh. Hal tersebut seperti dalam kutipan berikut.

"Mencermati kondisi yang tidak kondusif, Nanjan segera mengambil sikap.Ia berteriak lantang, mendiamkan huru hara-hara perdebatan dan pertengkaran. "sudah, sudah cukup. Cukup! Petengkaran tak menyelesaikan masalah. Perdebatan hanya akan memperkeruh suasana. Kembali pada nurani masing-masing. Bertanyalah ke nurani masing-masing: Adakah saya ingin merasakan hidup dengan cara lebih baik? Apa yang bisa saya lakukan, agar Jagoi Babang ini berkembang? Kalu malam ini kalian tak sependapat mengambil sikap, pikirkanlah cara bagaimana memajukan Jagoi Babang." (Irawan, 2015: 113)

Berdasarkan kutipan di atas, Nanjan berusaha dan berupaya agar suasana menjadi tenang.Dorongan ego membuat Nanjan ambil tindakan agar perdebatan dan pertengkaran bisa redah.

\section{Ketidaknyamanan dengan Kondisi yang Ada}

Ketidaknyamanan dengan kondisi yang ada merupakan faktor eksternal penyebab terjadinya konflik. Perhatikan kutipan ini :

"Kalau aku meninggal," Pang Ukir berkata setengah mengeluh,"Aku takut Semunying Jaya, Sikidak, Sentabeng, Sinar Baru dan Jagoi Babang tinggal nama. Hari Gawai tak ada lagi di tahun depan, di sini. Tanah ini menjadi asing, atau bahkan telah diserobot Malaysia dan diakui sebagai miliknya.(Irawan,2015:20)

Kutipan di atas, menggambarkan keadaan tempat tinggal Pang Ukir yang kurang Nyaman. Apa yang menyelimuti jiwa Pang Ukir ini adalah dorongan dari sistem egonya.

\section{Perbedaan Prinsip dan Pola Pikir}

Faktor eksternal penyebab konflik berupa perbedaan prinsip dan pola pikir, dan banyak dialami oleh tokoh.

"Begini saja, bagi siapa yang merasa hari depan yang lebih baik itu perlu untuk dipikirkan, siapa yang merasa kehidupan kita demi anak cucu kita, siapa yang merasa bahwa hidup yang labih baik itu perlu untuk diwujudkan, maka saya persilakanuntuk menandatangani kesepakatan bersama: Kita buat dokumen ganda. Ini jalan 
tengah yang saya tawarkan."(Irawan, 2015: 114)

Kutipan diatas,merupakan jalan pemikiran Nanjan.Dorongan sistem super ego membuat Nanjan ambil keputusan yang demikian.

\section{Kenyataan Tidak Sesuai Harapan}

Faktor eksternal penyebab terjadinya konflik karena kenyataan tidak sesuai dengan harapan, faktor tersebut banyak dialami oleh tokoh.

"Garuda ini kalian tahu selalu ada di dada ini. Warna merah putih itu, menjadi warna darahku.Dapatkan kalian melihat betapa air mataku berdarah-darah, menyaksikan merah putih yang semakin kusam berkibar-kibar? Lihatlah bendera Malaysia sana: Ia berkibar cemerlang di puncak-puncak galah yang tinggi, di atas tanah yang makmur di atas atap-atap rumah penduduk yang bahagia. Setiap kali memandang merah putih, aku merasa sedih dan sengsarah atas nasip kita yang tak pernah diperhatikan." (Irawan,2015:104)

Kutipan di atas melukiskan faktor penyebab keinginan tokoh yang tidak sesuai dengan harapan. Ungkapan kesedihan adalah pengaruh dari sistem idnya. Upaya membandingkan keadan Indonesia dengan Malaysia ini atas pengaruh dan dorongan dari sistem egonya.

\section{Hadirnya Pandangan Baru}

Hadirnya pandangan baru merupakan faktor eksternal penyebab terjadinya konflik tokoh dan salah satu faktor yang paling sedikit dialami tokoh. Seperti kutipan berikut ini.

"Hati Nanjan terasa sakit.Amat sakit. Kesakitan itulah yang ia bagi bersama Mamut dan temanteman sebayanya, hingga membuahkan keinginan bersama: Kita harus ikut pindah ke Malaysia!" "Menjadi warga Negara sana?" Mamut Bertanya. "Tentu. Seperti saudara-saudara kita yang lain"(Irawan,2015: 85)

Kutipan di atas, merupakan adanya indikator hadirnya pandangan baru.Di mana para kaum muda mau pindah ke malaysia agar harapan bisa hidup sejatera. Ini wujud dorongan sistem id.

\section{PEMBAHASAN}

Berdasarkan hasil penelitian yang telah dilakukan terhadap novel Kidung Rindu di Tapal Batas karya Aguk Irawan $\mathrm{MN}$, didapatkan beberapa hasil penelitian antara lain, (1) Wujud dinamika konflik; (2) faktor-faktor penyebab terjadinya konflik; (3) Penyelesaian Konflik tokoh .Langkahlangkah yang digunakan dalam mengumpulkan data penelitian ini adalah antara lain: a. Membaca berulang-ulang untuk memahami teks novel Kidung Rindu di Tapal Bataskarya Aguk Irawan MN sehingga dapat mengapresiasikan sumber data tersebut dan mencatat halhal yang akan dianalisis yang berhubungan dengan apa yang akan diteliti. b. Membaca dan mempelajari literatur, referensi atau bahan pustaka yang mempunyai hubungan dan menunjang terhadap persoalan dan permasalahan dalam penelitian ini. c. Mencatat dan memasukkan data yang di peroleh dari novel "Kidung Rindu di Tapal Batas" "karya Aguk Irawan MN ke dalam instrumen data, kemudian dianalisis sehingga didapat data yang sesuai dengan rumusan masalah dan tujuan penelitian.

\section{Wujud Dinamika Konflik Tokoh}

Konflik merupakan titik awal dari suatu permasalahan dalam suatu cerita. Masalah-masalah timbul dan terjadi karena adanya pertentangan atara satu tokoh, dua tokoh atau beberapa tokoh.Timbulnya konflik sering kali berhubungan dengan unsur watak. Karena watak tokoh sangat beragam dapat menimbulkan permasalahan dengan orang lain atau lingkungan sekitar. Keterkaitan tersebut disebabkan karena sebuah cerita yang tidak akan berjalan wajar dan menarik tanpa menghadirkan 
konflik yang menghidupkan jalannya cerita.

Adapun wujud dinamika konflik yang dialami oleh para tokoh dalam novel Kidung Rindu di Tapal Batas karya Aguk Irawan MN adalah sebagai berikut, Pertama, wujud dinamika konflik internal yang meliputi; kegelisahan terhadap apa yang sudah terjadi, ketakutan ditinggal warganya, kebingungan menghadapi dilema kehidupan, keinginan penghidupan yang lebih baik, ketakutan terhadap kematian, takut melukai perasaan orang lain, kekhawatiran yang beralasan, kekecewaan terhadap pengabdian yang kurang dihargai, perasaan bersalah atas perbuatannya, ketakutan terhadap perilaku yang diperbuat. Kedua, wujud dinamika konflik eksternalyang meliputi; perbedaan pendapat, ketakutan terhadap ancaman keamanan, perasaan yang dilukai, kekecewaan akibat kurang diperhatikan, pertentangan antara harapan dan kenyataan, bayangan kesulitan yang akan terjadi, pilihan yang sulit, ketidakpercayaan pada pemerintah, anggapan yang salah.

Penelitian ini relevan dengan penelitian yang dilakukan oleh rani Hidayatun (2004) dengan judul "Konflik psikologi tokoh utama dalam Novel Tuhan, Izinkan Aku Jadi Pelacur" (Kajian Psikologi Sastra). Penelitian ini membahas tentang konflik internal yang dialami tokoh utama. Hasil yang diperoleh menyatakan bahwa konflik tokoh terdiri atas konflik internal. Konflik internal disebabkan oleh keraguan, kebingungan, pertentangan, kekecewaan. Penyelesaian konflik internal yang dilakukan oleh tokoh merupakan proses berfikir yang dipengaruhi dunia subjektif dan objektif tokoh. Persamaan dengan penelitian ini adalah sama-sama melakukan penelitian konflik dalam kajian psikologi sastra.
Perbedaan penelitian Rani membahas konflik internal tokoh utama saja, sedangkan dalam penelitian ini membahas konflik internal dan konflik eksternal semua tokoh yang terdapat dalam novel Kidung Rindu di Tapal Batas karya Aguk Irawan MN.

\section{Faktor Penyebab Konflik Tokoh}

Para tokoh dalam novel Kidung Rindu di Tapal Batas banyak mengalami konflik, baik konflik internal maupun konflik eksternal.Terjadinya konflik tersebut disebabkan oleh beberapa faktor diantaranya adalah terjebak dalam situasi rumit,ketidaknyamanan dengan kondisi yang ada, perbedaan prinsip dan pola pikir, kenyataantidak sesuai dengan harapan, dan hadirnya pandangan baru.

Penelitian ini menggunakan teori psikoanalisis Freud.Freud mengemukakan bahwa struktur kepribadian manusia terbagi menjadi tiga struktur kepribadian.Ketiga struktur kepribadian tersebut, yaitu $i d$, ego dan super ego.Id merupakan keinginan dasar yang mendorong manusia untuk bertindak berdasarkan prinsip kenikmatan, berupa insting dan nafsu yang belum mengenal nilai.Ego merupakan sistem kepribadian yang bertindak sebagai pengaruh individu kepada dunia obyek dari kenyataan dan menjalankan fungsinya berdasarkan prinsip kenyataan.Ego biasanya mengawal dan menekan dorongan id yang kuat, mengubah sifat $i d$ dari yang abstrak dan gelap ke hal-hal yang berdasarkan pada prinsip kenyataan. Super ego merupakan penuntun moral dan berfungsi sebagai lapisan yang menolak suatu yang melanggar prinsip moral.

Penelitian ini sejalan dengan penelitian yang dilakukan oleh Ari Wulandari (2013) dengan judul perwatakan tokoh utama dalam novel 
Cintrong Paju-Pat karya Suparto Brata (sebuah kajian psikologi sastra). Persamannya Penelitian Ari Wulandari dengan penelitian ini adalah sama-sama mengunakan kajian psikologi sastra, teori yang digunakan juga sama-sama memakai teori Psikoanalisis Simon Freud. Perbedaannya penelitian Ari Wulandari hanya membahas tentang konflik psikologi tokoh utama saja, sedangkan penelitianini menekankan konflik yang dialami hampir semua tokoh.

\section{SIMPULAN DAN SARAN}

Hasil penelitian menunjukkan halhal berikut. Wujud dinamika konflik tokoh dalam novel Kidung Rindu di Tapal Batas karya Aguk Irawan MN yaitu konflik internal dan konflik eksternal. Kedua konflik tersebut memiliki sembilan belas substansi. Tiga substansi yang dominan dalam wujud konflik internal meliputi; 1) kegelisahan terhadap apa yang sudah terjadi, 2) ketakutan ditinggal warganya, 3) kebingungan menghadapi dilema kehidupan. Tiga Substansi yang dominan dalam wujud konflik eksternal meliputi 1) Perbedaan pendapat, 2) ketakutan terhadap ancaman keamanan, 3)perasaan yang dilukai.

Faktor penyebab terjadinya konflik dalam novel Kidung Rindu di Tapal Batas karya Aguk Irawan MN yaitu faktor eksternal yang berupa, 1) kenyataan tidak sesuai harapan, 2) kondisi lingkungan yang tidak mendukung, 3) hadirnya Pandangan baru,4) perbedaan prinsip dan pola pikir, dan 5) terjebak dalam situasi rumit.

Peneliti berharap agar siswa hendaknya dalam membaca novel memperhatikan unsur konflik yang dialami para tokohnya diantaranya; wujud konflik, sebab terjadinya konflik dan cara penyelesaian konfliknya dalamnovel, sehingga bisa faham tentang konflik yang terjadi.

Peneliti berharap guru hendaknya dapat memaksimalkan penggunaan bahan pembelajaran sastra, hasilpenelitian ini diharapkan mampu digunakan oleh guru bahasa sastra Indonesia di sekolah untuk dijadikan bahan referensi guru sebagai materi ajar khususnya materi sastra.

Peneliti berharap juga kepada masyarakat pembaca setelah membaca novel ini hendaknya pembaca bisa memahami seluk beluk konflik yang terjadi dan bisa menghubungkan dengan konflik yang sebenarnya terjadi pada masyarakat perbatasan sehingga pembaca mengetahui keadaan yang terjadi di daerah perbatasan.

\section{DAFTAR PUSTAKA}

Arikunto, Suharsimi. 2013. Prosedur Penelitian suatu Pendekatan Praktik. Jakarta: PT Rineka Cipta.

Endraswara, Suwardi. 2008. Metode Penelitian Psikologi Sastra. Yogyakarta: Media Pressindo.

Endraswara, Suwardi. 2013 Teori Kritik Sastra.Yogyakarta: CAPS (Center for Academic Publishing Service)

Hardjana, Andre.1985. Kritik Sastra Sebuah Pengantar. Jakarta: Gramedia.

Irawan, Aguk.2015. Kidung Rindu di Tapal Batas. Yogyakarta: Penerbit Qalam Nusantara.

Nurgiyantoro, Burhan. 2009. Teori Pengkajian Fiksi. Yogyakarta: Gadjah Mada University Press.

Wellek, Renedan Austin, Warren. 1998. Teori Kesusastraan (Terjemahan Melanie Budianta) Jakarta: PT Gramedia Pustaka Utama. 